\title{
Tracking of Interventions on Overweight and obese School Children: a Systematic literature review (2000-2014)
}

\author{
Wan Putri Elena WD*, Hamid Jan JM, Hafzan Y
}

Nutrition Programme, School of Health Sciences, Universiti Sains Malaysia, Kelantan, Malaysia

\begin{abstract}
Childhood obesity predisposes to adult obesity and increases the risk of many chronic diseases including type II diabetes, hypertension, cardiovascular disease as well as some types of cancer. This systematic review aimed to determine the effectiveness of diverse approaches used in dietary and physical activity based interventions in dealing with obesity among children. PUBMED, Science Direct, Scopus and Google Scholar digital databases were searched (January 2000 to December 2014) for longitudinal and randomized controlled trials with minimum duration of 6 weeks reporting weight changes as primary outcomes. Overall, 18 out of 27 studies are considered as "effective" based on a statistically significant reduction in body mass index (BMI) or skin-folds for the intervention group (IG). Growing evidence showed that school-based interventions which incorporate physical activity, parent's involvement and using more interactive and enjoyable intervention as a complement to nutrition education may help prevent children becoming overweight in the long term. This review provided an update of the evidence from studies designed to evaluate the interventions to prevent childhood obesity. However, a more innovative and attention captivating intervention such as in the form of serious video games are needed to enhance the effectiveness of conventional interventions targeting at children.
\end{abstract}

Keywords: childhood obesity; nutrition education; primary school children; school-based interventions.

\section{Introduction}

The increasing prevalence of childhood obesity in Malaysia possessed a major threat to the public health. This health problem is a result of imbalance between energy intakes and energy expenditure due to unhealthy diet, decreased levels of physical activity (PA) and sedentary lifestyles [1]. Obesity increases the risk of numerous chronic diseases including diabetes, hypertension, cardiovascular diseases and several types of cancer; thus, special attention should be paid to its prevention. Overweight or obese youth are less likely to compensate for excess energy intake throughout the day than normal-weight children [2]. Investigating the various strategies that reduce overweight and obesity by aiming healthy eating and PA is a crucial endeavour.

School is an ideal place to teach children about healthy eating as most children spend the greatest part of their time in school. It is the time when they are developing eating habits that provide the basis for eating patterns throughout their lives [3]. Quite large proportions of obesity prevention programmes have been carried out in schools reference. Thus, many studies have been published more recently. Therefore, we conducted an up-to-date review of published studies that evaluate the impact of nutrition education (NE) interventions on the body mass index (BMI) school children.

\section{Methods}

\section{Search strategy}

Studies published between January 2000 and December 2014 was searched from PUBMED, Science Direct, Scopus and Google Scholar. Reference lists from review articles and eligible original articles were also searched manually to identify any additional articles. Keywords used as "nutrition education/health education and promotion/obesity prevention/ intervention" AND "school children/overweight/obese/ BMI" AND "school programme/school intervention".

The search was limited to articles focusing school children population with restricting inclusion criteria to interventions with longitudinal, exploratory and randomized controlled trial (RCT) design. Included articles must have taken anthropometric measurement of body weight and should aim at decreasing BMI or weight.

A total of 78 articles were identified from electronic databases, other publications as well as from cross references. Of these, 51 were excluded due to the study design, measure other effect rather than BMI as primary outcome, the study published other languages and the outcomes presented in the dissertations, review articles and brief reports. Finally, only 27 studies met all the inclusion criteria and were included in this review. Literature search are summarized in Figure 1.

\section{Results}

The 27 studies were published between 2001 and 2014 and included a total of 18,545 participants. Six studies were conducted in the United States of America, five in United Kingdom, three in Germany, two in Brazil, China, Israel and Netherlands respectively and one study in Chile, France, New Zealand, Australia and Switzerland respectively. Most of the studies (19 studies) were long-term experiments (9 months -7 years) and the rest were short-term interventions (6 weeks - 6 months). The sample sizes varied greatly among the studies ranging from 60 to 3086 participants - Table 1 .

All of the interventions were conducted in school premises except for seven studies which conducted at paediatric obesity clinic, student

*Corresponding author: Wan Putri Elena Wan Dali, Nutrition Programme, School of Health Sciences, Universiti Sains Malaysia, Kubang Kerian 16150, Kelantan Malaysia. Tel: +60139594151; E-mail:wpelena@gmail.com

Received August 28, 2015; Accepted September 25, 2015; Published Septembe 30, 2015

Citation: Wan Putri Elena WD, Hamid Jan JM, Hafzan Y (2015) Tracking of Interventions on Overweight and obese School Children: a Systematic literature review (2000-2014). Health Care Current Reviews 3: 140. doi: 10.4172/23754273.1000140

Copyright: @ 2015 Wan Putri Elena WD, et al. This is an open-access article distributed under the terms of the Creative Commons Attribution License, which permits unrestricted use, distribution, and reproduction in any medium, provided the original author and source are credited. 
Citation: Wan Putri Elena WD, Hamid Jan JM, Hafzan Y (2015) Tracking of Interventions on Overweight and obese School Children: a Systematic literature review (2000-2014). Health Care Current Reviews 3: 140. doi: 10.4172/2375-4273.1000140

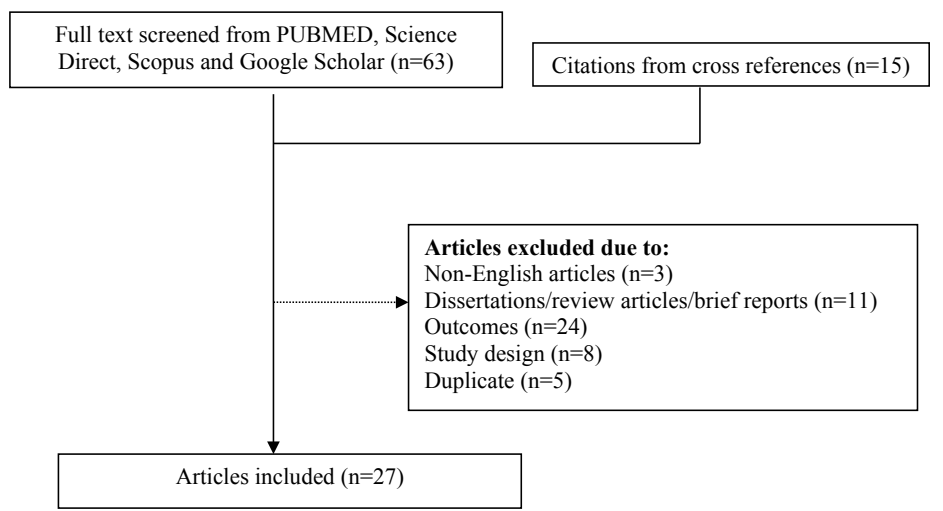

Figure 1: Flowchart of literature search.

\begin{tabular}{|c|c|c|c|c|c|}
\hline $\begin{array}{c}\text { Author, country } \\
\text { (year) }\end{array}$ & $\begin{array}{l}\text { Study design, } \\
\text { duration }\end{array}$ & Respondents & Intervention programme & Results & Limitations \\
\hline \multicolumn{6}{|c|}{ DIET ONLY STUDIES } \\
\hline $\begin{array}{l}\text { Cunha et al., } \\
\text { Brazil (2013) } \\
\text { [17] }\end{array}$ & $\begin{array}{l}\text { Cluster RCT } \\
\text { trial, 9-month }\end{array}$ & $\begin{array}{c}559 \\
(I G=277 \\
C G=282)\end{array}$ & $\begin{array}{l}9 \mathrm{NE} \text { sessions including playing } \\
\text { games, staging of theater sketches, } \\
\text { watching movies and puppet shows, } \\
\text { and writing and drawing contests }\end{array}$ & $\begin{array}{c}\text { - Decreased sugar-sweetened } \\
\text { beverages consumption } \\
\text { - Increased fruits consumption } \\
\text { - Motivation to change eating habits } \\
\text { increased over time. }\end{array}$ & $\begin{array}{l}\text { - Participant satisfaction was not } \\
\text { measured } \\
\text { - Dependent on memory (24hours } \\
\text { and FFQ) }\end{array}$ \\
\hline $\begin{array}{l}\text { Muckelbauer } \\
\text { et al., Germany } \\
(2009)[13]\end{array}$ & $\begin{array}{l}\text { Cluster RCT, } \\
\text { 1-year }\end{array}$ & $\begin{array}{c}2950(I G=1641 \\
C G=1309)\end{array}$ & $\begin{array}{l}\text { Combined environmental and } \\
\text { educational intervention promoting } \\
\text { water consumption }\end{array}$ & $\begin{array}{l}\text { - The risk of OW was significantly } \\
\text { reduced by } 31 \% \text { in the IG }\end{array}$ & - Did not evaluate dietary behaviors \\
\hline $\begin{array}{l}\text { James et al., UK } \\
\text { (2007) [15] }\end{array}$ & $\begin{array}{l}\text { Cluster RCT, } \\
\text { 2-year }\end{array}$ & $\begin{array}{l}434(\mathrm{IG}=219 \\
\quad \mathrm{CG}=215)\end{array}$ & $\begin{array}{l}\text { Focused education promoting a } \\
\text { healthy diet and discouraging the } \\
\text { consumption of carbonated drinks }\end{array}$ & $\begin{array}{c}\text { - BMI had decreased in IG } \\
\text { - The prevalence of OW increased in } \\
\text { both IG and CG }\end{array}$ & $\begin{array}{c}\text { - High dropout rate } \\
\text { - Consumption of carbonated drinks } \\
\text { was not measured }\end{array}$ \\
\hline $\begin{array}{l}\text { James et al., } \\
\text { UK (2004) [14] }\end{array}$ & $\begin{array}{l}\text { Cluster RCT, } \\
\text { 1-year }\end{array}$ & $\begin{array}{l}644(I G=325 \\
\quad C G=319)\end{array}$ & $\begin{array}{l}\text { Focused on the balance of good health } \\
\text { and promotion of drinking water, tasted } \\
\text { fruit to learn about the sweetness of } \\
\text { natural products, music competition, } \\
\text { presentations of art and quiz }\end{array}$ & $\begin{array}{c}\text { - The percentage of overweight and } \\
\text { obese as well as consumption of } \\
\text { carbonated drinks decreased }\end{array}$ & $\begin{array}{c}\text { - Contamination of RCT due to the } \\
\text { randomization was according to } \\
\text { classes not schools }\end{array}$ \\
\hline $\begin{array}{l}\text { Sichieri et al., } \\
\text { Brazil (2008) } \\
\text { [18] }\end{array}$ & $\begin{array}{l}\text { Cluster RCT, } \\
\text { 1-year school } \\
\text { (10 months) }\end{array}$ & $\begin{array}{l}1140(I G=435 \\
\quad C G=608)\end{array}$ & $\begin{array}{l}\text { Healthy lifestyle education using } \\
\text { simple messages encouraging water } \\
\text { consumption instead of sugar- } \\
\text { sweetened carbonated beverages }\end{array}$ & $\begin{array}{l}\text { - Non-significant reduction overall } \\
\text { BMI among children in IG } \\
\text { - But significantly reduced BMI } \\
\text { among girls who were OW in IG } \\
\text { - Significantly decreased the } \\
\text { consumption of carbonated drinks in IG }\end{array}$ & $\begin{array}{l}\text { - Slight family involvement } \\
\text { - Intervention may not have been } \\
\text { sufficiently intense or long enough } \\
\text { to change behavior }\end{array}$ \\
\hline
\end{tabular}

FFQ=Food Frequency Questionnaire; BMI=Body Mass Index; RCT=Randomized Controlled Trial; NE=Nutrition Education; IG=Intervention Group; CG=Control Group; OW=Overweight

\begin{tabular}{|c|c|c|c|c|c|}
\hline $\begin{array}{c}\text { Author, country } \\
\text { (year) }\end{array}$ & $\begin{array}{l}\text { Study design, } \\
\text { duration }\end{array}$ & Respondents & Intervention programme & Results & Limitations \\
\hline $\begin{array}{l}\text { Golan \& Crow, } \\
\text { Israel (2004) [6] }\end{array}$ & $\begin{array}{l}\text { Randomized } \\
\text { and longitudinal, } \\
\text { 7-year }\end{array}$ & $\begin{array}{c}60(I G=30 \\
C G=30)\end{array}$ & $\begin{array}{l}\text { 14 1-hour support and educational } \\
\text { group sessions; limits of } \\
\text { responsibilities, NE, eating and } \\
\text { activity behavior modification, } \\
\text { decreasing stimulus exposure, } \\
\text { parental modeling, problem solving, } \\
\text { cognitive restructuring and coping } \\
\text { with resistance }\end{array}$ & $\begin{array}{l}\text { Significant greater reduction of OW } \\
\text { children in IG compared to CG }\end{array}$ & Small sample size \\
\hline \multicolumn{6}{|c|}{ PA ONLY STUDIES } \\
\hline $\begin{array}{l}\text { Kriemler et al., } \\
\text { Switzerland } \\
(2010)[19]\end{array}$ & $\begin{array}{c}\text { Cluster RCT, } \\
\text { 1-year }\end{array}$ & $\begin{array}{c}502(I G=297 \\
C G=205)\end{array}$ & $\begin{array}{c}\text { Three existing PE lessons a week, } \\
\text { daily short activity breaks and PA } \\
\text { homework }\end{array}$ & $\begin{array}{c}\text { - Significantly improved PA and } \\
\text { fitness in IG } \\
\text { - Small increments of BMI and waist } \\
\text { circumference }\end{array}$ & No nutritional assessment \\
\hline $\begin{array}{l}\text { Thivel et al., } \\
\text { France (2011) } \\
{[20]}\end{array}$ & $\begin{array}{c}\text { Randomized and } \\
\text { longitudinal, } 6 \\
\text { months }\end{array}$ & $\begin{array}{c}457(I G=229 \\
C G=228)\end{array}$ & $\begin{array}{l}120 \text { minutes of supervised physical } \\
\text { exercise and } 2 \text { hours of PE classes } \\
\text { per week }\end{array}$ & $\begin{array}{l}\text { Improved significantly in terms of } \\
\text { aerobic and anaerobic physical } \\
\text { fitness }\end{array}$ & No nutritional assessment \\
\hline \multicolumn{6}{|c|}{ COMBINED DIET AND PA STUDIES } \\
\hline $\begin{array}{c}\text { Sahota et al., UK } \\
\text { (2001) [21] }\end{array}$ & $\begin{array}{c}\text { Cluster RCT, } 1 \\
\text { year }\end{array}$ & $\begin{array}{c}636(I G=314 \\
C G=322)\end{array}$ & $\begin{array}{l}\text { Teacher training, modification of } \\
\text { school meals, and the development } \\
\text { of school action plans targeting } \\
\text { the curriculum, PE, tuck shops and } \\
\text { playground activities }\end{array}$ & $\begin{array}{l}\text { - Vegetable consumption was } \\
\text { increased among IG. } \\
\text { - Unsuccessful in reducing risk } \\
\text { factors for obesity }\end{array}$ & $\begin{array}{c}\text { - Difficult to measure the accurate } \\
\text { dietary assessment } \\
\text { - Difficult to quantify the PA level }\end{array}$ \\
\hline
\end{tabular}

$\mathrm{PA}=$ Physical activity; $\mathrm{PE}=$ Physical education 
Citation: Wan Putri Elena WD, Hamid Jan JM, Hafzan Y (2015) Tracking of Interventions on Overweight and obese School Children: a Systematic literature review (2000-2014). Health Care Current Reviews 3: 140. doi: 10.4172/2375-4273.1000140

Page 3 of 6

\begin{tabular}{|c|c|c|c|c|c|}
\hline \begin{tabular}{|c|} 
Author, \\
country (year)
\end{tabular} & \begin{tabular}{|c|}
$\begin{array}{c}\text { Study design, } \\
\text { duration }\end{array}$ \\
\end{tabular} & Respondents & Intervention programme & Results & Limitations \\
\hline $\begin{array}{l}\text { Kain et al., } \\
\text { Chile (2004) } \\
\text { [22] }\end{array}$ & $\begin{array}{l}\text { Longitudinal } \\
\text { controlled } \\
\text { evaluation } \\
\text { study, } 6 \text { months }\end{array}$ & $\begin{array}{c}3086(\mathrm{IG}=2141 \\
\mathrm{CG}=945)\end{array}$ & $\begin{array}{c}\text { NE for children and parents, } \\
\text { 'healthier' kiosks, } 90 \text { min of additional } \\
\text { PA weekly, behavioral PA program } \\
\text { and active recess. }\end{array}$ & $\begin{array}{l}\text { Positive effect on adiposity indices } \\
\text { in boys while physical fitness } \\
\text { parameters increased in both boys } \\
\text { and girls }(<0.001)\end{array}$ & Non-randomized trial \\
\hline $\begin{array}{l}\text { Savoye et al., } \\
\text { Israel (2007) } \\
{[23]}\end{array}$ & $\mathrm{RCT}, 1$ year & $\begin{array}{l}174(\mathrm{IG}=105 \\
\mathrm{CG}=69)\end{array}$ & $\begin{array}{l}\text { Intensive family-based program } \\
\text { including exercise, nutrition and } \\
\text { behavior modification }\end{array}$ & $\begin{array}{l}\text { Significant reduction in BMI and body } \\
\text { fat }\end{array}$ & $\begin{array}{c}\text { - High dropout rate } \\
\text { - No measurable change in calories or } \\
\text { macronutrients }\end{array}$ \\
\hline $\begin{array}{c}\text { Foster et al., } \\
\text { USA (2008) [24] }\end{array}$ & $\mathrm{RCT}, 2$ years & $\begin{array}{l}844(I G=479 \\
C G=365)\end{array}$ & $\begin{array}{c}\text { School Nutrition Policy Initiative } \\
\text { includes: school self-assessment, NE, } \\
\text { nutrition policy, social marketing and } \\
\text { parent outreach }\end{array}$ & $\begin{array}{l}\text { The prevalence of OW was lower in } \\
\text { the IG schools }\end{array}$ & $\begin{array}{c}\text { The use of self report measures of } \\
\text { diet and exercise is less ideal than } \\
\text { direct measures }\end{array}$ \\
\hline $\begin{array}{c}\text { Jiang et al., } \\
\text { China (2007) [7] }\end{array}$ & $\mathrm{RCT}, 3$ years & $\begin{array}{c}2425(I G=1029 \\
C G=1396)\end{array}$ & $\begin{array}{l}\text { NE and PA through classes, } \\
\text { educational materials and text with } 10 \\
\text { themes. Including parents in IG }\end{array}$ & $\begin{array}{l}\text { - Prevalence of OW and obesity were } \\
\text { significantly reduced in IG. } \\
\text { - BMI did not decrease significantly } \\
\text { among severe obese children } \\
\text { during the intervention. }\end{array}$ & $\begin{array}{c}\text { Dietary intake, PA and obesity-related } \\
\text { behaviours were not measured }\end{array}$ \\
\hline $\begin{array}{l}\text { Sacher et al., } \\
\text { UK (2010) [25] }\end{array}$ & $\mathrm{RCT}, 12$ months & $\begin{array}{c}116(I G=60 \\
C G=56)\end{array}$ & $\begin{array}{l}\text { MEND is a multicomponent } \\
\text { community-based childhood obesity } \\
\text { intervention }\end{array}$ & $\begin{array}{c}\text { - Significant reduction of waist } \\
\text { circumference and BMI in IG } \\
\text { - Significant improvements for BP, PA } \\
\text { level, self-esteem and heart rate }\end{array}$ & $\begin{array}{l}\text { - High dropout rate } \\
\text { - Lack of blinding for measurement of } \\
\text { outcomes }\end{array}$ \\
\hline
\end{tabular}

$\mathrm{BP}=$ Blood pressure

\begin{tabular}{|c|c|c|c|c|c|}
\hline \begin{tabular}{|c|} 
Author, \\
country (year)
\end{tabular} & $\begin{array}{c}\text { Study design, } \\
\text { duration }\end{array}$ & Respondents & Intervention programme & Results & Limitations \\
\hline $\begin{array}{l}\text { Boutelle et al., } \\
\text { USA (2012) [26] }\end{array}$ & $\mathrm{RCT}, 11$ months & $\begin{array}{c}80(I G=40 \\
C G=40)\end{array}$ & $\begin{array}{c}\text { 5-month family based behavioral } \\
\text { weight loss program includes dietary } \\
\text { modification, increases in PA, } \\
\text { behavioral change skills and parenting } \\
\text { skills. }\end{array}$ & $\begin{array}{l}\text { Reduction of } 1 \mathrm{BMI} \text { unit in the parent } \\
\text { was associated with a } 0.255 \text { reduction } \\
\text { in child BMI. }\end{array}$ & $\begin{array}{c}\text { Unmeasured variables may act as } \\
\text { confounders that bias the observed } \\
\text { effects. }\end{array}$ \\
\hline $\begin{array}{l}\text { Caballero et } \\
\text { al., USA (2003) } \\
{[27]}\end{array}$ & $\mathrm{RCT}, 3$ years & $\begin{array}{c}1704(I G=879 \\
C G=825)\end{array}$ & $\begin{array}{l}\text { The intervention had four } \\
\text { components: i) classroom curriculum, } \\
\text { ii) food service, iii) physical activity } \\
\text { and iv) family involvement }\end{array}$ & $\begin{array}{c}\text { - No significant reduction in body } \\
\text { weight and BMI } \\
\text { - Knowledge, attitudes and behavior } \\
\text { were positively and significantly } \\
\text { changed. }\end{array}$ & High dropout rates \\
\hline $\begin{array}{l}\text { Vos et al., } \\
\text { Netherlands } \\
\text { (2011) [28] }\end{array}$ & $\mathrm{RCT}, 1$ year & $\begin{array}{c}81(I G=41 \\
C G=40)\end{array}$ & $\begin{array}{c}\text { Multidisciplinary lifestyle treatment } \\
\text { including medical, nutritional, physical } \\
\text { and psychological counseling }\end{array}$ & $\begin{array}{l}\text { - Significant reduction of BMI in IG } \\
\text { - Significant improvements of HRQoL }\end{array}$ & Intervention used was expensive \\
\hline $\begin{array}{l}\text { Schaefer et } \\
\text { al., Germany } \\
(2011) \text { [29] }\end{array}$ & $\mathrm{RCT}, 2$ years & $\begin{array}{c}76 \text { (pilot=19, } \\
I G=34, C G=23)\end{array}$ & $\begin{array}{l}\text { "Obeldicks light" based on PA training, } \\
\text { NE and behavior counseling for } \\
\text { overweight children and their parents }\end{array}$ & $\begin{array}{l}\text { - Skin fold thickness, BIA, waist } \\
\text { circumference and BP significantly } \\
\text { decreased. } \\
\text { - All the measurements remained } \\
\text { stable in the follow-up period }\end{array}$ & High drop-out rates \\
\hline
\end{tabular}

HRQoL=Health-related Quality of Life; BIA=Bioimpedence analyses

\begin{tabular}{|c|c|c|c|c|c|}
\hline $\begin{array}{c}\text { Author, } \\
\text { country (year) }\end{array}$ & $\begin{array}{c}\text { Study design, } \\
\text { duration }\end{array}$ & Respondents & Intervention programme & Results & Limitations \\
\hline $\begin{array}{l}\text { Warren et al., } \\
\text { UK (2003) [30] }\end{array}$ & RCT, 20 weeks & $\begin{array}{l}218(I G \mathrm{i}=56 \\
\mathrm{ii}=54, \mathrm{iii}=54 \\
\text { CG iv }=54)\end{array}$ & $\begin{array}{l}\text { Consisted of: i) Eat Smart, ii) Play } \\
\text { Smart, iii) Eat Smart Play Smart and } \\
\text { iv) Be Smart }\end{array}$ & $\begin{array}{c}\text { - Significant of nutrition knowledge } \\
\text { among group "Eat Smart" and "Eat } \\
\text { Smart Play Smart" } \\
\text { - Fruit and vegetable intake increased } \\
\text { significantly in group i and iv. } \\
\text { - No significant changes in the rates of } \\
\text { OW and obesity }\end{array}$ & $\begin{array}{l}\text { - Duration of the study was not } \\
\text { adequate. } \\
\text { - Assessment of diet, PA and nutrition } \\
\text { knowledge may not have been } \\
\text { sensitive enough } \\
\text { - Four interventions were conducted in } \\
\text { each of the schools, may have led to } \\
\text { contamination between IG } \\
\text { - Problems in targeting parents }\end{array}$ \\
\hline $\begin{array}{l}\text { Morgan et al., } \\
\text { USA (2014) } \\
{[31]}\end{array}$ & $\begin{array}{l}\text { Longitudinal, } \\
10 \text { weeks }\end{array}$ & $\begin{array}{c}106(I G=51 \\
C G=54)\end{array}$ & $\begin{array}{c}\text { i) Classroom NE to improve } \\
\text { nutrition } K A B \text {, ii) classroom PA to } \\
\text { increase fitness and } E E \text {, iii)a unique } \\
\text { technology-based component using } \\
\text { avatars to improve motivation, body } \\
\text { image and self-esteem }\end{array}$ & $\begin{array}{c}\text { - No significant changes in BMI, food } \\
\text { self-efficacy and actual food intake } \\
\text { - Improved their healthy food choice } \\
\text { intentions } \\
\text { - Ability to identify fatty foods and } \\
\text { general nutrition knowledge }\end{array}$ & $\begin{array}{l}\text { - Short time of intervention } \\
\text { - No follow up }\end{array}$ \\
\hline $\begin{array}{l}\text { Coleman et al., } \\
\text { USA (2005) } \\
\text { [32] }\end{array}$ & $\begin{array}{c}\text { Untreated, } \\
\text { matched } \\
\text { control group } \\
\text { design, } 3 \text { years }\end{array}$ & $\begin{array}{c}896(I G=423 \\
C G=473)\end{array}$ & $\begin{array}{l}\text { Community-based implementation of } \\
\text { the national Coordinated Approach To } \\
\text { Child Heatlh (CATCH) programme }\end{array}$ & No effect on weight from year to year & $\begin{array}{l}\text { - High dropout rate } \\
\text { - No measurement on dietary intake }\end{array}$ \\
\hline
\end{tabular}

$\mathrm{KAB}=\mathrm{Knowledge}$, attitude, behavior; $\mathrm{EE}=$ Energy expenditure 
Citation: Wan Putri Elena WD, Hamid Jan JM, Hafzan Y (2015) Tracking of Interventions on Overweight and obese School Children: a Systematic literature review (2000-2014). Health Care Current Reviews 3: 140. doi: 10.4172/2375-4273.1000140

Page 4 of 6

\begin{tabular}{|c|c|c|c|c|c|}
\hline $\begin{array}{c}\text { Author, } \\
\text { country (year) }\end{array}$ & \begin{tabular}{|c|}
$\begin{array}{c}\text { Study design, } \\
\text { duration }\end{array}$ \\
\end{tabular} & Respondents & Intervention programme & Results & Limitations \\
\hline $\begin{array}{l}\text { Hofsteenge et } \\
\text { al., Netherlands } \\
\text { (2014) [33] }\end{array}$ & RCT, 18 months & $\begin{array}{c}122(\mathrm{IG}=71 \\
\mathrm{CG}=51)\end{array}$ & $\begin{array}{c}\text { Education on healthy dietary, } \\
\text { sedentary and PA for } 7 \text { sessions } \\
\text { (duration } 90 \text { minutes) with an interval } \\
\text { of } 2 \text { to } 3 \text { weeks }\end{array}$ & $\begin{array}{l}\text { - Significant reduction in BMlsds } \\
\text { - No significant effect in body } \\
\text { composition or metabolic } \\
\text { components }\end{array}$ & $\begin{array}{l}\text { - High level of drop out } \\
\text { - No exercise programme provided }\end{array}$ \\
\hline $\begin{array}{c}\text { Luo et al., China } \\
\text { (2013) [34] }\end{array}$ & $\mathrm{RCT}, 6$ weeks & $\begin{array}{c}167(\mathrm{IG}=95 \\
\mathrm{CG}=72)\end{array}$ & $\begin{array}{l}\text { Received well-defined and balanced } \\
\text { daily meals and engaged in high } \\
\text { volumes of moderate exercise } \\
\text { (6days/week, twice daily for } 3 \text { hours } \\
\text { per session) }\end{array}$ & $\begin{array}{c}\text { Significantly reduced levels for all } \\
\text { outcome markers except for FBI in } \\
\text { boys }\end{array}$ & $\begin{array}{l}\text { - Short-term period } \\
\text { - No follow-up assessment }\end{array}$ \\
\hline $\begin{array}{c}\text { Small et al., } \\
\text { USA (2013) [35] }\end{array}$ & RCT, 6 months & $\begin{array}{l}60(\mathrm{IG}=33 \\
\mathrm{CG}=27)\end{array}$ & $\begin{array}{l}\text { Establishment of healthy habits in } \\
\text { young children, nutritional information, } \\
\text { information regarding increasing PA } \\
\text { and decreasing sedentary time }\end{array}$ & $\begin{array}{l}\text { Reduction of waist circumference } \\
\text { in IG }\end{array}$ & Small sample size \\
\hline $\begin{array}{c}\text { Graf et al., } \\
\text { Germany (2008) } \\
{[36]}\end{array}$ & $\begin{array}{l}\text { Longitudinal, } 4 \\
\text { years }\end{array}$ & $\begin{array}{l}611(\mathrm{IG}=433 \\
\mathrm{CG}=178)\end{array}$ & $\begin{array}{l}\text { Children's Health Interventional Trial } \\
\text { (the CHILT Project) combines health } \\
\text { education and PA for children }\end{array}$ & $\begin{array}{c}\text { - No difference in the prevalence of } \\
\text { OW and obesity was found in IG } \\
\text { and CG } \\
\text { - Increment in endurance } \\
\text { performance in IG }\end{array}$ & $\begin{array}{l}\text { - Health knowledge and nutritional } \\
\text { habit were not measured. } \\
\text { - The schools were not randomly } \\
\text { assigned to IG and CG }\end{array}$ \\
\hline
\end{tabular}

$\mathrm{FBI}=$ Fasting Blood Insulin

\begin{tabular}{|c|c|c|c|c|c|}
\hline $\begin{array}{c}\text { Author, } \\
\text { country (year) }\end{array}$ & $\begin{array}{c}\text { Study design, } \\
\text { duration }\end{array}$ & Respondents & Intervention programme & Results & Limitations \\
\hline $\begin{array}{l}\text { Maddison et al., } \\
\text { New Zealand } \\
\text { (2011) [10] }\end{array}$ & RCT, 6 months & $\begin{array}{c}322(I G=160 \\
\quad C G=162)\end{array}$ & $\begin{array}{l}\text { Upgrade (hardware and games) } \\
\text { of existing gaming technology that } \\
\text { enabled them to play active video } \\
\text { games at home }\end{array}$ & $\begin{array}{l}\text { Body fat and BMI in IG were } \\
\text { significantly reduced. }\end{array}$ & $\begin{array}{l}\text { - Self-developed food and video } \\
\text { game diaries } \\
\text { - Some children were recruited } \\
\text { through schools, a potential for } \\
\text { contamination }\end{array}$ \\
\hline $\begin{array}{c}\text { Trost et al., } \\
\text { Australia (2014) } \\
\text { [11] }\end{array}$ & RCT, 16 weeks & $\begin{array}{l}75(I G=34 \\
C G=41)\end{array}$ & $\begin{array}{c}\text { Game console and motion capture } \\
\text { device and active game at their } \\
\text { second treatment session and } \\
\text { a second game in week } 9 \text { of the } \\
\text { program }\end{array}$ & $\begin{array}{l}\text { Participants in IG exhibited } \\
\text { significantly greater reductions in } \\
\text { percentage OW compared to CG. }\end{array}$ & $\begin{array}{l}\text { Intervention is too expensive and may } \\
\text { be a barrier for low-income families }\end{array}$ \\
\hline
\end{tabular}

Table 1: Details of the included intervention studies.

physical fitness, pediatric primary care and at home. Nine studies used a single intervention; two just physical educations and six just educations on nutrition. The remaining of eighteen studies used combination of these two or more interventions. Only ten studies have involved parents in their intervention. In total, 20 interventions included a physical component such as conducting moderate exercise including brisk walking, jogging and swimming, 21 interventions included education on nutrition or classroom lessons which receiving the nutritional information, information regarding increasing PA and decreasing sedentary time and establishment eating habits. Other than that, two studies included a counseling component, three studies involved video games components and two studies received cognitive behavioral therapy.

Eighteen studies are considered effective according to height/ weight measures, skin-folds or both. More than half of the studies had a high percentage of participants completing the study and this may be a reflection of various factors such as small sample sizes, short-study periods and nature of the intervention.

\section{Discussion}

This updated review provides useful data on published studies and expands the spectrum of information that should make it more useful for public health decision makers. Overall, the absolute reduction in BMI was greater for interventions targeted at overweight and obese children by using different types of interventions. There is accumulating evidence that school-based interventions can significantly reduce children's BMI, especially when including physical exercise components, parental involvements and using interactive, enjoyable but effective intervention to prevent the obesity.
In this review, 18 out of 27 studies considered as "effective" based on a statistically significant reduction in BMI or skin-folds for the intervention group (IG). Previously, more than half of the studies reviewed by Doak et al., [4] also showed a significant effect in reducing the prevalence of overweight and obesity. However, nine studies in this review were not successful in reducing the BMI. One possible reason for this situation is because it is difficult to make changes to behavior in an environment which increasingly promotes a high energy intake and sedentary activity [5].

There was sufficient evidence to conclude the influence of parental involvement in reducing their children's weight. Study conducted by Golan and Crow [6] has pointed out that a family-based, healthcentered approach that targeted solely parents was found to induce greater weight loss in obese children. "Don't encourage your child to eat more when the child feels full" was a major message in the study for the parents to implement which was carried out by Jiang et al., [7] and showed the positive result in reducing the overweight and obesity among their children. Educating for both parents and their children, give the complex interactions between social determinants in a family setting which is essential to the success for an intervention [8]. Thus, the involvement of parents in educational process enables them to become suitable models for their children, assuming a key role in building their dietary habits.

Despite of the growing number of overweight and obese college students, few studies were not applied the PA components in their interventions. A research conducted by Franko et al., [9] has shown that limited PA could likely lead to the risk of osteoporosis, obesity, hyperlipidemia, diabetes and cancer in later life. Because of video games based nutrition programmes are relatively new, it is not surprising 
Citation: Wan Putri Elena WD, Hamid Jan JM, Hafzan Y (2015) Tracking of Interventions on Overweight and obese School Children: a Systematic literature review (2000-2014). Health Care Current Reviews 3: 140. doi: 10.4172/2375-4273.1000140

that only few studies have been published in this area specifically for children. Only three studies [7, 10-11] have evaluated the effects of using video games and reported significant increases in daily PA. Serious video games offered innovative and enjoyable channels for effective behavior change. In addition, child's attentions have been attracted, modeling, tailoring, and feedback can increase personal relevance, and games add fun [12]. As such, the need for enjoyable, healthy and effective prevention of overweight and obesity is generally considered to be urgent.

Other findings that applied different components of education but effectively in reducing the BMI were also identified. One study in primary schools in deprived areas in Germany in which a reduction in overweight was found in intervention schools which received drinking water fountains with provision of drink bottles and related lessons [13]. Another study in UK which has involved children aged $7-11$ years from primary schools found that educational sessions and activities designed to reduce carbonated drink consumption led to decrease in the percentage of overweight and obese children of $0.2 \%$ compared to an increase of $7.5 \%$ in the CG over a follow-up period of 12 months [14]. After two years, the same studies also provide the best result with experimentally conclusive and sustainable evidence [15].

In terms of methodology, there is a clear need for the continuation of research, using better and larger studies with a long follow-up and improved research methodologies. The findings from few studies in this review have not described whether the environmental changes made during the interventions are maintained subsequently. Baranowski et al., [16] has suggested that intensities and durations of intervention programme over extended periods of intervention made should be analyzed and evaluated to ensure the effectiveness of the interventions. In addition, the reliability and validity of the interventions were not comprehensively reported, elements which are essential for judging the effectiveness of the interventions.

\section{Limitations of this study}

The majority of the included studies took place in the USA or northern Europe which limits the generalisability for the rest of the world, since the obsegenic environment is supported by increasingly complex social, political and cultural environments which may be unique to a particular country. In addition, the studies not indexed in PUBMED, Science Direct or Scopus and unpublished studies were not identified which is less-biased to provide more comprehensive review. Duration of the study can be a limiting factor for high dropout rate which can be seen in some intervention studies lasting over one year. Other than that, the instruments used in several studies were selfreported measures (except for the anthropometric measurements) which were highly dependent on the participants' memory, honesty and truthfulness in answering the questions. For this reason, the results may not reveal the actual dietary intake and eating behaviors of the participants and hence self-report bias may have occurred as the diet was unobserved.

\section{Conclusion}

Despite the unavoidable limitations, encouraging and positive results have been demonstrated via most studies. The characteristics of the interventions that demonstrated effectiveness are as follows: duration longer than 1 year, involvements of parents, allied to PA components and introduction of interactive, healthy and practical intervention via video games rather than using traditional or conventional interventions which are more practical for the current generation nowadays.

\section{References}

1. Summerbell CD, Waters E, Edmunds LD, Kelly S, Brown T, et al. (2005) Interventions for preventing obesity in children. Cochrane Database Syst Rev : CD001871.

2. Krebs NF, Himes JH, Jacobson D, Nicklas TA, Guilday $P$, et al. (2007) Assessment of child and adolescent overweight and obesity. Pediatrics 120 Suppl 4: S193-228.

3. Contento IR, Randell JS, Basch CE (2002) Review and analysis of evaluation measures used in nutrition education intervention research. J Nutr Educ Behav 34: 2-25.

4. Doak CM1, Visscher TL, Renders CM, Seidell JC (2006) The prevention of overweight and obesity in children and adolescents: a review of interventions and programmes. Obes Rev 7: 111-136.

5. Swinburn B, Egger G (2002) Preventive strategies against weight gain and obesity. Obes Rev 3: 289-301.

6. Golan M, Crow S (2004) Targeting parents exclusively in the treatment of childhood obesity: long-term results. Obes Res 12: 357-361.

7. Jiang J, Xia X, Greiner T, Wu G, Lian G, et al. (2007) The effects of a 3-year obesity intervention in schoolchildren in Beijing. Child Care Health Dev 33: 641 646.

8. Guy S1, Ratzki-Leewing A, Gwadry-Sridhar F (2011) Moving beyond the stigma: systematic review of video games and their potential to combat obesity. Int J Hypertens 2011: 179124.

9. Franko DL, Cousineau TM, Trant M, Green TC, Rancourt D, et al. (2008) Motivation, self-efficacy, physical activity and nutrition in college students: randomized controlled trial of an internet-based education program. Preventive Medicine 47: 369-77

10. Maddison R, Foley L, Mhurchu CN, Jiang Y, Jull A, et al. (2011) Effects of active video games on body composition: a randomized controlled trial. American Journal of Clinical Nutrition: 1-8.

11. Trost SG, Sundal D, Foster GD, Lent MR, Vojta D (2014) Effects of a pediatric weight management program with and withput active video games. A randomized trial. Journal of American Medical Association: 1-8.

12. Baranowski T, Baranowski J, Thompson D, Buday R, Jago R, et al. (2011) Video game play, child diet, and physical activity behavior change a randomized clinical trial. Am J Prev Med 40: 33-38.

13. Muckelbauer R, Libuda L, Clausen K, Toschke AM, Reinehr T, et al. (2009) Promotion and provision of drinking water in schools for overweight prevention: randomized, controlled cluster trial. Pediatrics 123: e661-667.

14. James J, Thomas P, Cavan D, Kerr D (2004) Preventing childhood obesity by reducing consumption of carbonated drinks: cluster randomised controlled trial. BMJ 328: 1237.

15. James J, Thomas P, Kerr D (2007) Preventing childhood obesity: two year follow-up results from the Christchurch obesity prevention programme in schools (CHOPPS). BMJ: 1-4.

16. Baranowski T, Buday R, Thompson DI, Baranowski J (2008) Playing for real video games and stories for health-related behavior change. Am J Prev Med 34: 74-82.

17. Cunha DB, de Souza Bda S, Pereira RA, Sichieri R (2013) Effectiveness of a randomized school-based intervention involving families and teachers to prevent excessive weight gain among adolescents in Brazil. PLoS One 8: e57498.

18. Sichieri R, Paula Trotte A, de Souza RA, Veiga GV (2009) School randomised trial on prevention of excessive weight gain by discouraging students from drinking sodas. Public Health Nutr 12: 197-202.

19. Kriemler S, Zahner L, Schindler C, Meyer U, Hartmann T, et al. (2010) Effect of school based physical activity programme (KISS) on fitness and adiposity in primary schoolchildren cluster randomized controlled trial. BMJ 340: 1-8.

20. Thivel D, Isacco L, Lazaar N, Aucouturier J, Ratel S, et al. (2011) Effect of a 6-month school-based physical activity program on body composition and physical fitness in lean and obese schoolchildren. Eur J Pediatr 170: 14351443.

21. Sahota P, Rudolf MCJ, Dixey R, Hill AJ, Barth JH, et al. (2001) Randomised controlled trial of primary school based intervention to reduce risk factors for obesity. BMJ 323: 1029-1032. 
Citation: Wan Putri Elena WD, Hamid Jan JM, Hafzan Y (2015) Tracking of Interventions on Overweight and obese School Children: a Systematic literature review (2000-2014). Health Care Current Reviews 3: 140. doi: 10.4172/2375-4273.1000140

22. Kain J, Uauy R, Albala, Vio F, Cerda R, et al. (2004) School-based obesity prevention in Chilean primary school children: methodology and evaluation of a controlled study. Int J Obes Relat Metab Disord 28: 483-493.

23. Savoye M, Shaw M, Dziura J, Tamborlane WV, Rose P, et al. (2007) Effects of a weight management program on body composition and metabolic parameters in overweight children. Journal of American Medical Association 297: 26972704.

24. Foster GD, Sherman S, Borradaile KE, Grundy KM, Vander Veur SS, et al. (2008) A policy-based school intervention to prevent overweight and obesity. Pediatrics 121: e794-802.

25. Sacher PM, Kolotourou M, Chadwick PM, Cole TJ, Lawson MS, et al. (2010) Randomized controlled trial of the MEND program: a family-based community intervention for childhood obesity. Obesity (Silver Spring) 18 Suppl 1: S62-68.

26. Boutelle KN, Cafri G, Crow SJ (2012) Parent predictors of child weight change in family based behavioral obesity treatment. Obesity (Silver Spring) 20: 15391543.

27. Caballero B, Clay T, Davis SM, Ethelbah B, Rock BH, et al. (2003) Pathways: a school-based, randomized controlled trial for the prevention of obesity in American Indian schoolchildren. Am J Clin Nutr 78: 1030-1038.

28. Vos RC, Huisman SD, Houdijk EC, Pijl H, Wit JM (2012) The effect of familybased multidisciplinary cognitive behavioral treatment on health-related quality of life in childhood obesity. Qual Life Res 21: 1587-1594.

29. Schaefer A, Winkel K, Finne E, Kolip P, Reinehr T (2011) An effective lifestyle intervention in overweight children: one year follow-up after the randomized controlled trial on "Obeldicks light". Clinical Nutrition 30: 629-633.
30. Warren JM, Henry CJ, Lightowler HJ, Bradshaw SM, Perwaiz S (2003) Evaluation of a pilot school programme aimed at the prevention of obesity in children. Health Promot Int 18: 287-296.

31. Morgan AZ, Ulrich P, Simmons KP, Gropper SS, Connell LJ, et al. (2014) Effectiveness of a multi-faceted, school-based health intervention program with 4th graders in Alabama. Children and Youth Services Review 37: 46-54.

32. Coleman KJ, Tiller CL, Sanchez J, Heath EM, Sy O, et al. (2005) Prevention of the epidemic increase in child risk of overweight in low-income schools: the El Paso coordinated approach to child health. Arch Pediatr Adolesc Med 159: 217-224.

33. Hofsteenge GH, Chinapaw MJ2, Delemarre-van de Waal HA3, Weijs PJ4 (2014) Long-term effect of the Go4it group treatment for obese adolescents: a randomised controlled trial. Clin Nutr 33: 385-391.

34. Luo B, Yang Y, Niemean DC, Zhang Y, Wang J, et al. (2013) A 6-week diet and exercise intervention alters metabolic syndrome risk factors in obese Chinese aged 11-13 years. Journal of Sport and Health Science 2: 236-241.

35. Small L, Bonds-McClain D, Melnyk B, Vaughan L, Gannon AM (2014) The preliminary effects of a primary care-based randomized treatment trial with overweight and obese young children and their parents. J Pediatr Health Care 28: 198-207.

36. Graf C, Koch B, Falkowski G, Jouck S, Christ H, et al. (2008) School-based prevention: effects on obesity and physical performance after 4 years. J Sports Sci 26: 987-994 